\title{
A Decade of Improvements in Mimiviridae and Marseilleviridae Isolation from Amoeba
}

\author{
Isabelle Pagnier $^{a}$ Dorine-Gaelle Ikanga Reteno ${ }^{a}$ Hanene Saadi ${ }^{a}$ \\ Mondher Boughalmi ${ }^{a}$ Morgan Gaia ${ }^{a}$ Meriem Slimani ${ }^{a}$ Tatsiana Ngounga ${ }^{a}$ \\ Meriem Bekliz ${ }^{a}$ Philippe Colson ${ }^{a}$ Didier Raoult ${ }^{a}, b$ Bernard La Scola ${ }^{a}$ \\ a Unité de Recherche sur les Maladies Infectieuses et Tropicales Emergentes (URMITE), Aix-Marseille Université,

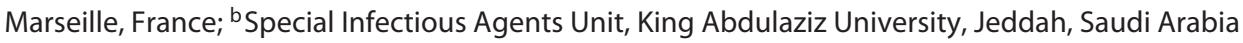

\author{
Key Words \\ Mimivirus · Marseillevirus · Megavirus · Megavirales . \\ Virophage $\cdot$ Acanthamoeba
}

\begin{abstract}
Since the isolation of the first giant virus, the Mimivirus, by T.J. Rowbotham in a cooling tower in Bradford, UK, and after its characterisation by our group in 2003, we have continued to develop novel strategies to isolate additional strains. By first focusing on cooling towers using our original time-consuming procedure, we were able to isolate a new lineage of giant virus called Marseillevirus and a new Mimivirus strain called Mamavirus. In the following years, we have accumulated the world's largest unique collection of giant viruses by improving the use of antibiotic combinations to avoid bacterial contamination of amoeba, developing strategies of preliminary screening of samples by molecular methods, and using a high-throughput isolation method developed by our group. Based on the inoculation of nearly 7,000 samples, our collection currently contains 43 strains of Mimiviridae (14 in lineage $A, 6$ in lineage $B$, and 23 in lineage $C$ ) and 17 strains of Marseilleviridae isolated from various environments, including 3 of human origin. This study details the procedures used to build this collection and paves the way for the high-
\end{abstract}

throughput isolation of new isolates to improve the record of giant virus distribution in the environment and the determination of their pangenome.

(c) 2013 S. Karger AG, Basel

\section{Introduction}

Mimivirus, the first giant virus identified, was isolated from an amoeba in Bradford, UK, in the 1980s during the investigation of a pneumonia outbreak by T.J. Rowbotham while he was trying to isolate Legionella-like bacterial pathogens that infect amoebae $[1,2]$. Acanthamoeba polyphaga Marseillevirus was isolated in France 5 years later during work to isolate other strains of mimiviruses [3]. Those two viruses are the founding members of two new viral families. Members of the two new viral families are the largest known viruses based on the sizes of their capsid and genome. Mamavirus, another member of the Mimiviridae, was later isolated and found to harbour a virophage [4], and other members of the Marseilleviridae have been recovered from the Seine River [5] and from human stool [6]. The isolation of several strains of the giant viruses made it possible to classify them as members of a new order of Megavirales [7]. This order is divided

\begin{tabular}{ll}
\hline KARGER & $\begin{array}{l}\text { () 2013 S. Karger AG, Basel } \\
0300-5526 / 13 / 0566-0354 \$ 38.00 / 0 \quad \text { Karger }\end{array}$ \\
$\begin{array}{l}\text { E-Mail karger@karger.com } \\
\text { www.karger.com/int }\end{array}$ & $\begin{array}{l}\text { This is an Open Access article licensed under the terms of the } \\
\text { Creative Commons Attribution-NonCommercial 3.0 Un- } \\
\text { ported license (CC BY-NC) (www.karger.com/OA-license), } \\
\text { applicable to the online version of the article only. Distribu- } \\
\text { tion permitted for non-commercial purposes only. }\end{array}$
\end{tabular}

Prof. Bernard La Scola

Unité de Recherche sur les Maladies Infectieuses et Tropicales Emergentes (URMITE) UM63, CNRS 7278, IRD 198, Inserm 1095, Faculté de Médecine, Aix-Marseille Université 27, boulevard Jean-Moulin, FR-13385 Marseille Cedex 05 (France)

E-Mail bernard.la-scola@univ-amu.fr 
into two distinct groups. The first group contains the Mimiviridae family, which is divided into 3 lineages (A, $\mathrm{B}$ and $\mathrm{C}$ ), and the Marseilleviridae family [8]. The second is represented by the single Cafeteria roenbergensis virus $\mathrm{CroV}$, which is found in a unicellular marine biflagellate [9]. However, the first three isolates of Megavirales were obtained from fastidious amoeba coculture procedures on water samples from cooling towers. For many years, we have tried to improve our isolation procedures and have tested many biotopes to investigate the distribution of giant viruses. We report herein the cumulative results of this work, which have enabled the isolation of 18 strains of Marseilleviridae and 45 strains of Mimiviridae from diverse environments, including human samples.

\section{Methods}

\section{Sampling and Preparation of Samples}

A variety of samples were used when seeking amoeba-associated giant viruses, including water, soil, insect, stool or human respiratory samples. The different types of samples analysed for the presence of giant viruses are summarised in figure 1 . In the original procedure, 500- to 1,000-ml water samples stored in sterile bottles were kept at $4^{\circ}$ before processing. Samples were then filtered through a $0.22-\mu \mathrm{m}$-pore filter to concentrate all microorganisms larger than this size, and the filters were vortexed in 1-2 $\mathrm{ml}$ of sterile Page's amoebal saline (PAS) buffer $[1,3,10]$. Next, to isolate 'small' giant viruses, $0.22-\mu \mathrm{m}$-pore membranes were replaced by $0.1-\mu \mathrm{m}$-pore membranes [6]. Other samples from tap water and biofilms were sampled using sterile swabs and were directly vortexed in 1-2 ml of sterile PAS [11]. The latest improvement for simplifying the water sampling procedure involved sampling $10-50 \mathrm{ml}$ of water followed by a high-speed centrifugation step (15,000 rpm for $10 \mathrm{~min})$. This procedural modification concentrated the microorganisms and was faster than the original filtration procedure.

For soil samples, each 15- to 100-gram sample was mixed with $50-150 \mathrm{ml}$ of sterile water. Decantation was performed for 24$48 \mathrm{~h}$ at $4^{\circ}$ followed by filtration through Whatman paper and then through a $0.1-\mu \mathrm{m}$ membrane. The membranes were then added to $1 \mathrm{ml}$ of PAS and vortexed following the same procedure as that used for the water samples [11-13].

The same principle used for the soil samples was applied to the processing of stool samples. Briefly, $50 \mathrm{ml}$ of water was added to approximately $1 \mathrm{~g}$ of stool sample, decantation was then carried out for $24-48 \mathrm{~h}$ at $4^{\circ}$, and the supernatants were filtered through a $0.1-\mu \mathrm{m}$ membrane. The membranes were then added to $1 \mathrm{ml}$ of PAS and vortexed [6].

For the respiratory samples such as sputum or bronchoalveolar lavage, mechanical breakdown of the cells was performed by passing the samples through syringes of $0.33 \mathrm{~mm}$ diameter (bioMérieux, Marcy l'Etoile, France). The samples were then inoculated directly onto the amoebal monolayer for giant virus research [14].

Other types of samples, such as samples from insect larvae or leeches, required more specific treatments. The animals were first rinsed with $96 \%$ ethanol to sterilise their exterior, then washed with sterile PAS and dissected to separate the digestive tract and internal organs from the rest of the body. The digestive tract and internal organs were crushed together with $3 \mathrm{ml}$ of PAS buffer, and the suspension was homogenised. A solution consisting of 4 antibiotics (ciprofloxacin at $4 \mathrm{mg} / \mathrm{l}$, vancomycin at $4 \mathrm{mg} / \mathrm{l}$, colimycin at $500 \mathrm{IU} / \mathrm{l}$ and rifampicin at $4 \mathrm{mg} / \mathrm{l}$ ) and 1 antifungal (Fungizone at $100 \mathrm{mg} / \mathrm{l}$ ) was added to the suspensions to prevent bacterial and fungal contamination. The homogenised suspensions were then washed in PAS buffer to remove traces of the antimicrobial solution. The pellets were resuspended in PAS buffer and used for coculture with amoebae [15].

\section{Cocultures}

Primary Procedure. The amoebae A. polyphaga (strain Linc AP1) or A. castellanii were cultivated in PYG medium (proteose peptone, yeast extract, glucose) and subcultured every 2 days until confluent cell monolayers were obtained. For inoculation, a culture of amoeba was rinsed in PAS buffer using successive low-speed centrifugations at 2,000 rpm for $10 \mathrm{~min}$. The amoebae were counted in counting slides and were adjusted to $5 \times 10^{5}$ amoebae $/ \mathrm{ml}$ in PAS. The amoebal suspensions were distributed in 12-well microplates and $100 \mu \mathrm{l}$ of the sample suspensions were inoculated into the wells. Amoebal microplates were screened with an inverted microscope to detect amoebal lysis. The cocultures were then subcultured onto a fresh amoebal microplate suspension and the subcultures were also screened for amoebal lysis. The lysed cocultures were shaken to suspend the remaining amoebae, and $100 \mu \mathrm{l}$ of the suspension was cytocentrifuged at $800 \mathrm{rpm}$ for $10 \mathrm{~min}$. The slides were stained using Gram and Gimenez stains. When the presence of viruses was suspected, bacteria were removed from the culture using an appropriate antimicrobial agent or by filtration through $0.8-\mu \mathrm{m}$-pore filters. The presence of the giant virus was assessed by electron microscopic observation of cultures negatively stained with a $1 \% \mathrm{am}$ monium molybdate suspension. The giant virus was then measured, and the size enabled primary classification into the Mimiviridae group (capsid size of approximately $450 \mathrm{~nm}$ ) or the Marseilleviridae group (capsid size of approximately $200 \mathrm{~nm}$ ). Following classification, the single virus amoeba culture was subcultured for endpoint dilution cloning and further analyses. Nearly all cultures required antibiotics to eliminate bacterial contamination. Due to this necessity, the method was improved by the systematic use of antibiotics in the early stages of the procedure. This primary procedure has been described previously $[3,10]$.

Antibiotic-Directed Procedure. Amoebal microplates were prepared with amoebae under the same conditions as described above. Each sample was inoculated onto amoebal microplates with both colistin at $500 \mathrm{UI} / \mathrm{l}$ and vancomycin at $10 \mathrm{mg} / \mathrm{l}$. The cocultures were subcultured onto a fresh amoebal microplate suspension. The primary cultures and subcultures were screened daily for cytopathogenic effects using an inverted microscope and 100- $\mu \mathrm{l} \mathrm{sam-}$ ples of resuspended amoebae were cytocentrifuged. The slides were stained with Gimenez and Gram stains followed by additional Hemacolor staining (Merck, Darmstadt, Germany) if obvious viral factories inside the amoebae were noticed. On day 7 of the culture, $50 \mu \mathrm{l}$ of each coculture was systematically subcultured onto axenic media, buffered charcoal yeast extract agar and Columbia sheep blood agar plates to evaluate and eliminate residual bacterial contamination. The antimicrobial susceptibility of the isolates was tested using a disk diffusion assay with gentamicin, cotrimoxazole, erythromycin, rifampicin, doxycycline and ciprofloxacin. If bacterial overgrowth was moderate, the antibiotics that 


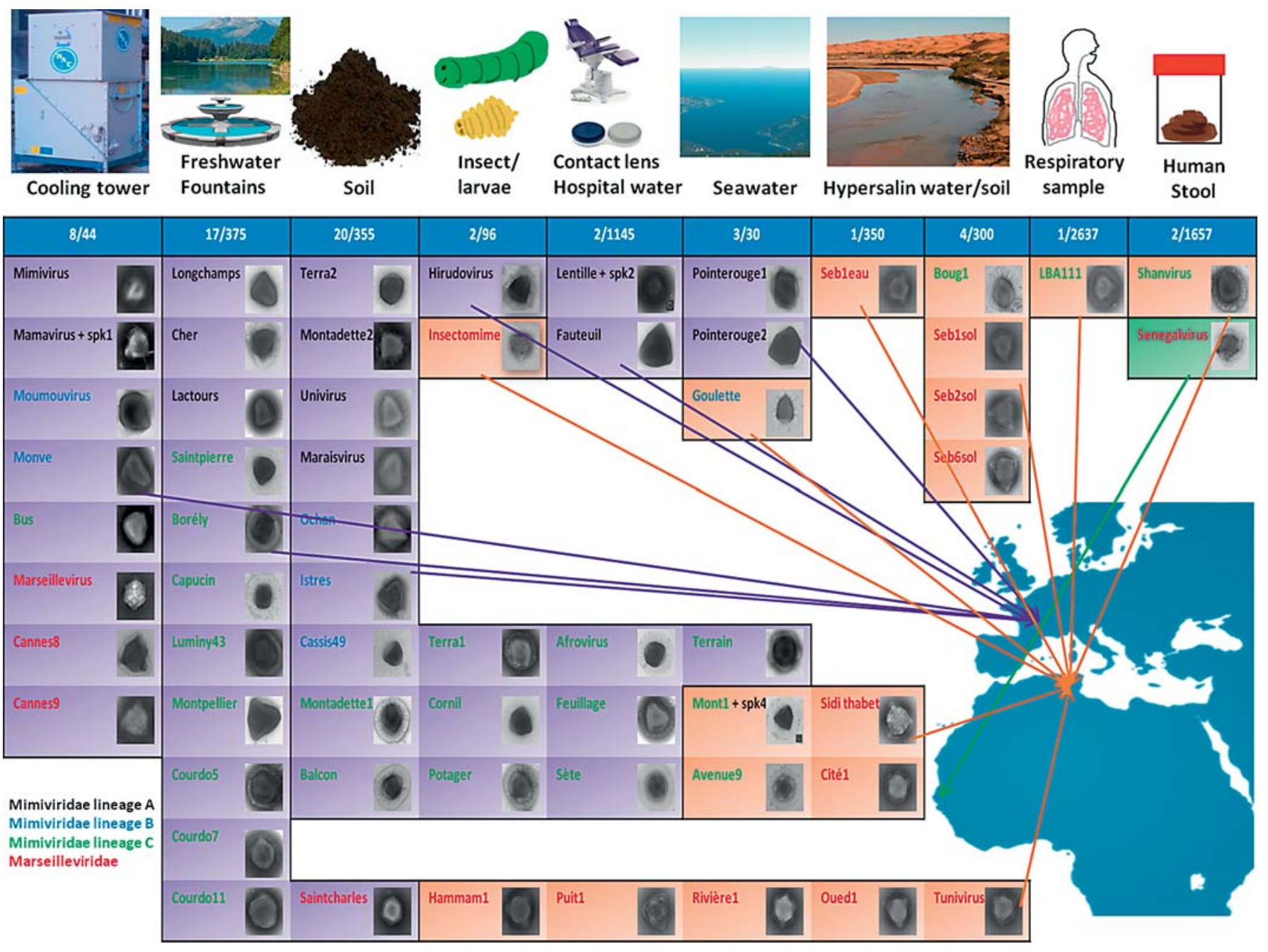

Fig. 1. A collection of giant viruses isolated in our laboratory from 6,989 samples according to the origin of the samples and grouped by species/genotype.

proved to be effective on the isolated bacteria were added to the subcultures. If bacterial overgrowth was massive and destroyed the amoeba monolayer, the sample was re-inoculated and supplemented with one or more of the effective antibiotics. In cases in which the bacterial overgrowth was due to bacteria that did not grow on agar plates, different antibiotics were tested on subcultures or re-inoculations until complete decontamination was achieved. When bacterial decontamination was evident, the cultures were treated as previously described with the single isolated virus. This antibiotic-directed procedure has been described previously [11].

High-Throughput Procedure. As described above, the initial enrichment step consisted of inoculating $100 \mu \mathrm{l}$ of the samples onto an amoeba monolayer in 12-well microplates without the addition of antibiotics. A subculture was made after 3 days on a fresh amoebal culture with the addition of antibiotics. The antibiotic cocktail used was improved and consisted of ciprofloxacin at $4 \mathrm{mg} / \mathrm{l}$, vancomycin at $4 \mathrm{mg} / \mathrm{l}$, colimycin at $500 \mathrm{IU} / \mathrm{l}$, rifampicin at $4 \mathrm{mg} / \mathrm{l}$ and amphotericin B at $100 \mathrm{mg} / \mathrm{l}$. Agar plates were prepared by adding $15 \mathrm{~g}$ of agar (Research Organics, Cleveland, Ohio, USA) to a 1-litre solution of PAS medium followed by sterilisation in an autoclave. The agar medium was supplemented before solidification with the same antibiotic cocktail as described above and 50-ml volumes were distributed into square Petri dishes $(23.5 \times 23.5 \mathrm{~cm}$; Dominic Deutscher, Brumath, France). After solidification, the agar was coated with a monolayer of amoebae diluted to $2 \times 10^{6} \mathrm{amoeba} / \mathrm{ml}$, and a drop of viral enrichment supernatant was inoculated on the monolayer. After incubation, as a virus multiplied, a lysis plaque could be visualised with the naked eye (fig. 2). The lysis plaques were measured, and the agar under the plaque was cut and divided into small pieces, resuspended in $1 \mathrm{ml}$ of PAS, vortexed and filtered through a $1.2-\mu \mathrm{m}$-pore filter before inoculation with fresh amoebae in PAS buffer. After this step, single viruses in suspension were treated as previously described. This high-throughput procedure has been described previously [12]. 
Fig. 2. Illustration of plaque lysis using the high-throughput method of stained agar plates according to Gaia et al. [13]. a The cross indicates the sites of inoculation and the squares 1 and 2 indicate the area of lysis for 2 samples, whereas positive controls are located in area 3. Magnification of lysis obtained by Mimivirus (b) and Marseillevirus (c).
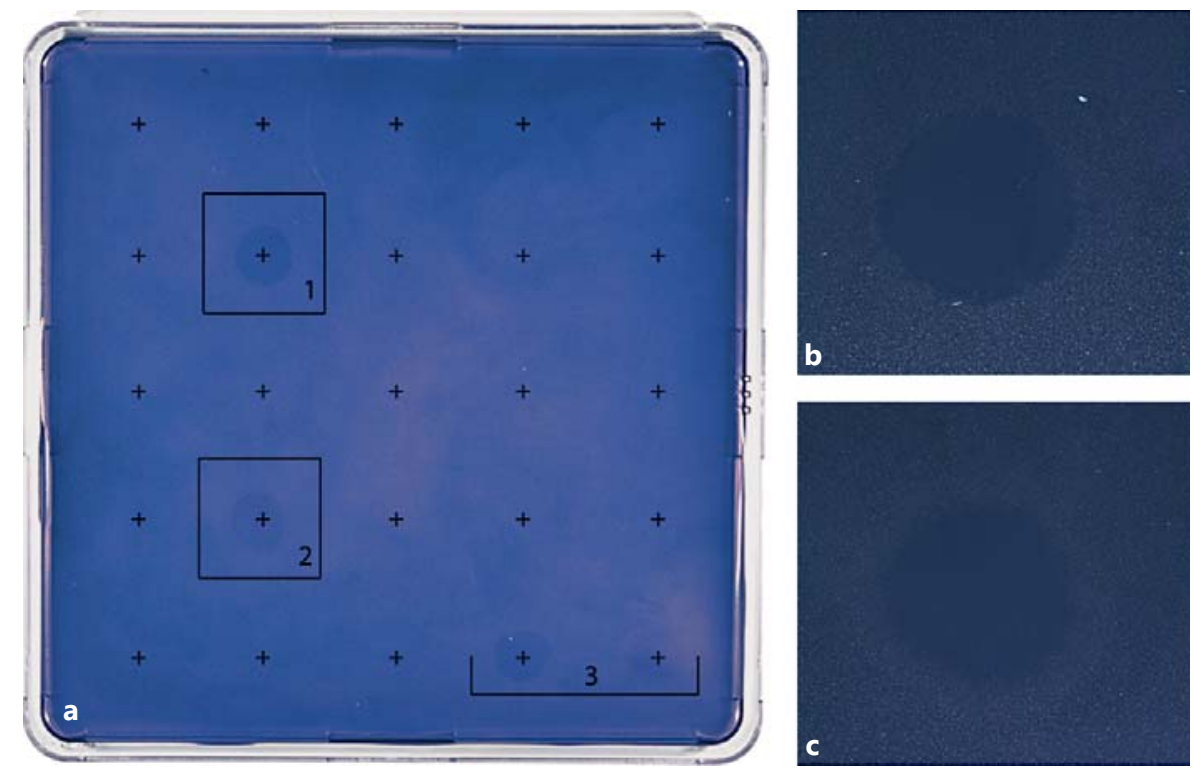

Additional Enrichment by Blind Subculture Combined with the High-Throughput Procedure. This method uses ciprofloxacin at 20 $\mathrm{mg} / \mathrm{l}$, vancomycin at $10 \mathrm{mg} / \mathrm{l}$, imipenem at $10 \mathrm{mg} / \mathrm{l}$ and thiabendazole at $50 \mathrm{mg} / \mathrm{l}$ (Sigma-Aldrich, Saint-Quentin Fallavier, France). Thiabendazole was used to avoid fungal contamination, which often occurs with soil samples. Thiabendazole replaced amphotericin B because it showed a higher toxicity for amoebae. The coculture procedure consisted of a primary coculture step using the new antibiotic cocktail for 3 days at $32^{\circ}$. After the 3 -day antibiotic treatment step, filtration through $0.8-\mu \mathrm{m}$-pore membranes was used to reduce fungal contamination when thiabendazole treatment was not sufficient. Plates were then subcultured onto a fresh amoebal monolayer with the same antimicrobial agent cocktail with the omission of thiabendazole. An additional enrichment step was added to the previous procedure by subculturing onto a fresh amoeba monolayer containing the same antibiotic cocktail. After this final enrichment step, the culture supernatants were inoculated onto amoebal monolayers deposited on agar plates, as described for the previous high-throughput method.

\section{Molecular Screening of Samples}

In several studies, we intended to improve the efficiency of the culture yield by selecting the samples to be inoculated based on an initial molecular screening step. In an initial study [13], 90 soil samples were screened by standard PCR using primer pairs specifically targeting the three lineages (A, B and C) of Mimiviridae. The primers used were targeted to the beta subunit of the DNA polymerase ( $p o l B$ ) based on the genome sequencing of Mimivirus and Terra2 for group A, Moumouvirus for group B, and Courdo11 and Terra1 for group $\mathrm{C}$ (table 1). The viral DNA was extracted from the samples using a QIAGEN ${ }^{\odot}$ QIAmp Mini Kit (Qiagen GmbH, Hilde, Germany) according to the manufacturer's instructions. Standard PCR amplification was performed and the PCR products were visualised under UV light after migration on an agar gel stained with ethidium bromide. In a second study, we modified the detection of giant viruses using real-time PCR with TaqMan specific primer- probe systems. The tentative detection of mimiviruses from group C was performed on 156 soil samples. The primer-probe system was designed to target a gene encoding a hypothetical protein from the group C Mimiviridae system CE7-1675721 (table 1). DNA extraction was performed as described above, and real-time PCR was performed by adding $5 \mu$ of DNA to an amplification mix containing $12.5 \mu \mathrm{l}$ of $2 \times$ QuantiTect Probe PCR Master Mix, $0.5 \mu \mathrm{l}$ of TaqMan probe and $0.5 \mu \mathrm{l}(0.2 \mu \mathrm{mol})$ of both reverse and forward primers in a final reaction volume of $25 \mu \mathrm{l}$. Amplifications were performed on a thermocycler Light Cycler (Roche, Meylan Cedex, France) with an initial enzyme activation step $\left(95^{\circ}, 10 \mathrm{~min}\right)$ followed by 40 cycles of denaturation $\left(95^{\circ}, 30 \mathrm{~s}\right)$ and hybridisation/ elongation $\left(60^{\circ}, 1 \mathrm{~min}\right)$. More recently, we developed primer-probe systems to extend the preliminary molecular detection to all Mimiviridae (groups A, B and C) and Marseilleviridae. DNA extraction was performed with the automated extraction system EZ1 Virus MiniKit v.2 (Qiagen $\mathrm{GmbH}$ ) following the manufacturer's instructions. Real-time PCR was performed by adding $5 \mu \mathrm{l}$ of DNA to the amplification mix containing $12.5 \mu \mathrm{l}$ of $2 \times$ QuantiTect Probe PCR Master Mix, $0.5 \mu \mathrm{l}$ of TaqMan probe, and $0.5 \mu \mathrm{l}(0.2 \mu \mathrm{mol})$ of both reverse and forward primers in a final reaction volume of $25 \mu \mathrm{l}$. The reactions were run on a CFX96 ${ }^{\mathrm{TM}}$ thermocycler (BioRad Laboratories Inc., Hercules, Calif., USA) with an enzyme activation step $\left(95^{\circ}, 15 \mathrm{~min}\right)$ followed by 44 cycles of denaturation $\left(95^{\circ}, 30 \mathrm{~s}\right)$ and hybridisation/elongation $\left(60^{\circ}, 1 \mathrm{~min}\right)$.

\section{PCR Primary Characterisation}

As explained above, the initial identification of giant viruses was first based on the direct observation of the culture suspension. First, samples stained with Gram or Hemacolor stains were observed under a light microscope at $100 \times$ magnification. Second, negative staining was performed using a $1 \%$ solution of ammonium molybdate and observation under an electron microscope. Because of the design and application of the specific primer-probe systems listed in table 1, amplification and sequencing of viral genes allows a more precise preliminary classification of the newly isolated viruses into 
Table 1. Sequences of different primers and probes used to amplify specific genes of Mimiviridae groups A, B and C, and Marseillevirus

\begin{tabular}{|c|c|c|c|c|}
\hline Group & Primer/probe & Sequence $\left(5^{\prime}-3^{\prime}\right)$ & Viral group & Target gene \\
\hline A & $\begin{array}{l}\text { Mimi-TJA01F } \\
\text { Mimi-TJA01R } \\
\text { Mimi-TJA02F } \\
\text { Mimi-TJA02R } \\
\text { CE11-TE1-01F } \\
\text { CE11-TE1-01R } \\
\text { CE11-TE1-01F } \\
\text { CE11-TE1-01R } \\
\text { VA10-01F } \\
\text { VA10-01R }\end{array}$ & $\begin{array}{l}5^{\prime} \text {-GCAGCCCTTTGACACTT-3' } \\
5^{\prime} \text {-CATGCGGGAGTTGGAGA-3' } \\
5^{\prime} \text {-GAAAATGGTGAAGAGAAAACTGA-3' } \\
5^{\prime} \text {-ACCAGGATAAATGGATGCAA-3' } \\
5^{\prime} \text {-AGTTACCCAACCACAAGAAGA-3' } \\
5^{\prime} \text {-CAGAAGGACTAACAAAAGAACCA-3' } \\
5^{\prime} \text {-AAAATATTGGGGACGTTGGTG-3' } \\
5^{\prime} \text {-ATGGAAGACTGGCTGTTGAAA-3' } \\
5^{\prime} \text {-AAGGGGACAAGGAGTTAAAATAT-3' } \\
5^{\prime} \text {-TAGATATACGTTTGGTTTTGGAGTGA-3' }\end{array}$ & $\begin{array}{l}\text { mimiviridae A } \\
\text { mimiviridae A } \\
\text { mimiviridae A } \\
\text { mimiviridae A } \\
\text { mimiviridae C } \\
\text { mimiviridae C } \\
\text { mimiviridae C } \\
\text { mimiviridae C } \\
\text { mimiviridae B } \\
\text { mimiviridae B }\end{array}$ & polB \\
\hline $\mathrm{C}$ & $\begin{array}{l}\text { A865F2 } \\
\text { A865R1 } \\
\text { A865 Prb2 }\end{array}$ & $\begin{array}{l}5^{\prime} \text {-TGGATACATTGATGGTTGATAA-3' } \\
5^{\prime} \text {-TTTCGACTTTACACTTGGGATTG-3' } \\
\text { FAM-TTATGAAAAACCTAATCCAGAAGATT-TAMRA }\end{array}$ & $\begin{array}{l}\text { mimiviridae A } \\
\text { mimiviridae A } \\
\text { mimiviridae A }\end{array}$ & $\begin{array}{l}\text { hypothetical } \\
\text { protein }\end{array}$ \\
\hline $\mathrm{B} / \mathrm{C}$ & $\begin{array}{l}\text { CE7-1675721FPr2 } \\
\text { CE7-1675721RPr1 } \\
\text { CE7-1675721 Prb1 }\end{array}$ & $\begin{array}{l}5^{\prime} \text {-TAATTTTATATTCAACACCAAGG-3' } \\
5^{\prime} \text {-CCAATGACCTATCGTTGG-3' } \\
\text { FAM-CTTGGTCTAACAACCAAACACTA-TAMRA }\end{array}$ & $\begin{array}{l}\text { mimiviridae } C \\
\text { mimiviridae } C \\
\text { mimiviridae } C\end{array}$ & $\begin{array}{l}\text { hypothetical } \\
\text { protein }\end{array}$ \\
\hline $\mathrm{C}$ & $\begin{array}{l}\text { Mars_Fwd1 } \\
\text { Mars_Rev1 } \\
\text { Mars_Pr1 }\end{array}$ & $\begin{array}{l}5^{\prime} \text {-TCTGGGAGTGGGCTTTATCT-3' } \\
\text { 5'-AGGGTAATGACCTCGGGTA-3' }^{\prime} \text { 'AM-AGGATTGAACCTTCGCTGTTAC-TAMRA }\end{array}$ & $\begin{array}{l}\text { marseilleviridae } \\
\text { marseilleviridae } \\
\text { marseilleviridae }\end{array}$ & $\begin{array}{l}\text { hypothetical } \\
\text { protein }\end{array}$ \\
\hline
\end{tabular}

the Mimiviridae groups A, B or C, or Marseilleviridae group. DNA was extracted from the positive culture samples using the automated extraction system EZ1 Virus MiniKit v.2 (Qiagen GmbH). Realtime PCR was performed as described above using a CFX96 ${ }^{\mathrm{TM}}$ thermocycler (BioRad Laboratories Inc.), and sequencing was conducted using the same primers that were used for amplification.

\section{Results}

\section{Number of Isolated Strains}

Since the isolation of the first giant virus, Mimivirus, methodological improvements have led to the isolation of 43 strains of Mimiviridae (14 from lineage A, 6 from lineage $B$ and 23 from lineage C) and 17 strains of Marseilleviridae (fig. 1). They are all classified within group I of Megavirales, which includes the Marseilleviridae and Mimiviridae lineages A, B and C [7].

\section{Nature of the Positive Samples}

After the isolation of the first Mimivirus in 2003 from the water of an air conditioning system, the second strain, named A. castellanii Mamavirus, was found in a cooling tower [4]. In addition, the first Marseillevirus strain was also found in the water of a cooling tower in 2009 [3]. In 2010, La Scola et al. [11] isolated 3 new strains of Mimivirus (Moumouvirus, Monve and Bus) and 2 new strains of Marseillevirus (Cannes8 and Cannes9) from 39 cooling water samples. During the same study, other types of environmental water was investigated, and the authors were able to isolate 8 strains of Mimiviridae and 1 strain of Marseilleviridae (Saintcharles) from 53 freshwater samples, such as fountains, lakes, rivers and hospital water. Moreover, La Scola et al. [11] tested 2 soil samples and 10 seawater samples. Both soil samples were positive for Mimiviridae (Terra1 and Terra2), and 2 out of the 10 seawater samples were positive for Mimiviridae (Pointerouge 1 and Pointerouge2). This was the first time that giant viruses were isolated from an ecological system other than from the water of a cooling tower. Based on the observation that giant viruses can also be found in other environments, a study was performed focusing on hypersaline water and soil samples from Tunisia [12], and another study focused on diverse soil samples collected around Marseille, in the south of France [13]. Both stud- 
Table 2. Main features of Mimiviruses and Marseilleviruses isolated in our laboratory

\begin{tabular}{|c|c|c|c|c|c|c|c|}
\hline Family & Name & Source & Country/region & $\begin{array}{l}\text { Capsid } \\
\text { size } \\
(\mathrm{nm})\end{array}$ & $\begin{array}{l}\text { GenBank } \\
\text { accession } \\
\text { no. }\end{array}$ & $\begin{array}{l}\text { Genome } \\
\text { size }(n t)\end{array}$ & $\begin{array}{l}\text { Refer- } \\
\text { ence }\end{array}$ \\
\hline \multicolumn{8}{|c|}{ Mimiviridae $(n=43)$} \\
\hline \multirow[t]{14}{*}{ Group A $(\mathrm{n}=14)$} & $\begin{array}{l}\text { A. polyphaga } \\
\text { Mimivirus }\end{array}$ & Cooling tower water & UK (Bradford) & 400 & NC_014649 & $1,181,549$ & {$[1,2]$} \\
\hline & $\begin{array}{l}\text { A. castellanii } \\
\text { Mamavirus }\end{array}$ & Cooling tower water & France (Paris) & 450 & JF801956 & $1,191,693$ & {$[4]$} \\
\hline & Terra2 & Soil & France (Marseille) & 370 & - & $1,170,000$ & {$[11]$} \\
\hline & Pointe-Rouge2 & Seawater & France (Marseille) & 500 & - & $1,160,000$ & {$[11]$} \\
\hline & Cher & Rivers and lakes & France (Tours) & 420 & - & - & {$[11]$} \\
\hline & Fauteuil & Hospital water & France (Marseille) & 600 & - & $1,180,000$ & {$[11]$} \\
\hline & Longchamps & $\begin{array}{l}\text { Decorative fountain } \\
\text { water }\end{array}$ & France (Marseille) & 450 & - & $1,103,000$ & {$[11]$} \\
\hline & Lactours & Rivers and lakes & France (Tours) & 450 & - & $1,180,000$ & {$[11]$} \\
\hline & Pointe-Rouge1 & Seawater & France (Marseille) & 390 & - & $1,146,000$ & {$[11]$} \\
\hline & Lentille & Lens liquid & France (Marseille) & 500 & JF979182 & $1,220,000$ & {$[11]$} \\
\hline & Marais & Swamp & France (Aubagne) & - & - & $1,197,000$ & $\mathrm{NP}$ \\
\hline & Univirus & Compost & France (Marseille) & - & - & $1,087,000$ & NP \\
\hline & Hirudovirus & Leech & France (Marseille & - & - & - & NP \\
\hline & Montadette2 & Soil & France (Martigues) & - & - & - & $\mathrm{NP}$ \\
\hline \multirow[t]{6}{*}{ Group B $(n=6)$} & Moumouvirus & Cooling tower water & France (Rousset) & 420 & JX962719 & $1,021,421$ & {$[11]$} \\
\hline & Monve & Cooling tower water & France (Puget sur Argens) & 390 & $\begin{array}{l}\text { JN885994- } \\
\text { JN886001 }\end{array}$ & $1,015,033^{\mathrm{b}}$ & {$[11]$} \\
\hline & Ochan & Compost & France (Marseille) & - & - & $1,026,000$ & $\mathrm{NP}$ \\
\hline & Goulette & Seawater & Tunisia (Tunis) & - & - & $1,026,000$ & {$[10]$} \\
\hline & Istres & Soil & France (Istres) & - & - & - & NP \\
\hline & Cassis49 & Soil & France (Cassis) & - & - & - & NP \\
\hline \multirow[t]{23}{*}{ Group C $(n=23)$} & Courdo7 & Rivers and lakes & France (Saint-Raphaël) & 400 & $\begin{array}{l}\text { JN885990- } \\
\text { JN885993 }\end{array}$ & $1,170,106^{\mathrm{b}}$ & {$[11]$} \\
\hline & Terra1 & Soil & France (Marseille) & 420 & - & $1,230,000$ & {$[11]$} \\
\hline & Montpellier & $\begin{array}{l}\text { Decorative fountain } \\
\text { water }\end{array}$ & $\begin{array}{l}\text { France } \\
\text { (Montpellier) }\end{array}$ & 370 & - & $1,225,000$ & {$[11]$} \\
\hline & Courdo11 & Rivers and lakes & France (Saint-Raphaël) & 450 & - & $1,245,674$ & {$[11]$} \\
\hline & Courdo5 & Rivers and lakes & France (Marseille) & 400 & - & - & {$[11]$} \\
\hline & Bus & Cooling tower water & France (Marseille) & 400 & - & $1,227,000$ & {$[11]$} \\
\hline & Mont1 & Soil (mountain) & Tunisia (Tunis) & - & - & - & {$[10]$} \\
\hline & LBA111 & Broncholalveolar lavage & Tunisia & - & - & $1,230,519$ & {$[13]$} \\
\hline & Avenue9 & Soil & Tunisia (Tunis) & - & - & $1,214,000$ & {$[10]$} \\
\hline & Afrovirus & Soil & France (Aubagne) & - & - & - & NP \\
\hline & Montadette1 & Soil & France (Martigues) & - & - & - & NP \\
\hline & Balcon & Soil & France (Marseille) & - & - & - & NP \\
\hline & $\begin{array}{l}\text { Terrain en } \\
\text { construction }\end{array}$ & Soil & France (Marseille) & - & - & - & NP \\
\hline & Boug1 & Chott (hypersaline soil) & Tunisia (Gafsa) & - & - & - & {$[10]$} \\
\hline & Shan & Stool & Tunisia (Tunis) & - & - & - & $\mathrm{NP}$ \\
\hline & Cornil & Soil & France (Marseille) & - & - & - & NP \\
\hline & Saint Pierre & Stagnant water & France (Marseille) & - & - & - & NP \\
\hline & Borély & Stagnant water & France (Marseille) & - & - & - & NP \\
\hline & Capucin & Stagnant water & France (Marseille) & - & - & - & NP \\
\hline & Potager & Soil & France (Marseille) & - & - & - & NP \\
\hline & Feuillage & Soil & France (Martigues) & - & - & - & NP \\
\hline & Luminy43 & Water & France (Marseille) & - & - & - & NP \\
\hline & Sète & Soil & France (Sète) & - & - & - & NP \\
\hline
\end{tabular}


Table 2 (continued)

\begin{tabular}{|c|c|c|c|c|c|c|c|}
\hline Family & Name & Source & Country/region & $\begin{array}{l}\text { Capsid } \\
\text { size } \\
(\mathrm{nm})\end{array}$ & $\begin{array}{l}\text { GenBank } \\
\text { accession } \\
\text { no. }\end{array}$ & $\begin{array}{l}\text { Genome } \\
\text { size (nt) }\end{array}$ & $\begin{array}{l}\text { Refer- } \\
\text { ence }\end{array}$ \\
\hline \multirow[t]{2}{*}{ Marseillevirus $(\mathrm{n}=2)$} & Marseillevirus & Cooling tower water & France (Cannes) & 190 & JF979175.1 & 374,000 & {$[3]$} \\
\hline & Senegalvirus & Stool & Senegal & - & $\begin{array}{l}\text { JF909596- } \\
\text { JF909602 }\end{array}$ & 386,000 & [9] \\
\hline \multirow{9}{*}{ Unassigned $(\mathrm{n}=14)$} & Cannes9 & Cooling tower water & France (Cannes) & 150 & - & - & [11] \\
\hline & Saint-Charles & $\begin{array}{l}\text { Decorative fountain } \\
\text { water }\end{array}$ & France (Marseille) & 230 & - & 376,000 & {$[11]$} \\
\hline & Seb1 eau & Sebkha (hypersaline water) & Tunisia (Tunis) & - & - & - & {$[10]$} \\
\hline & Seb1 sol & Soil (hypersaline soil) & Tunisia (Tunis) & - & - & - & {$[10]$} \\
\hline & Seb6 sol & Soil (hypersaline soil) & Tunisia (Tunis) & - & - & - & [10] \\
\hline & Puit1 & Well water & Tunisia (Cap Bon) & - & - & - & {$[10]$} \\
\hline & Hammam1 & Hammam water & Tunisia (Tunis) & - & - & - & {$[10]$} \\
\hline & Sidi thabet & Soil & Tunisia (Ariana) & - & - & - & {$[10]$} \\
\hline & Insectomime & Diptere larvae & Tunisia & - & - & - & {$[14]$} \\
\hline
\end{tabular}

$\mathrm{NP}=$ Unpublished data.

ies resulted in the isolation of Mimiviridae and Marseilleviridae in all of the environments that were sampled. Moreover, both studies led to the isolation of virophages: Sputnik 3 [13] and Sputnik 4 [12]. Later, we explored the possibility that giant viruses were eventually found in human samples (respiratory and stool samples) and animals (i.e. insects and leeches), which further expanded the known ecological niches of giant viruses $[14,15]$.

\section{Direct Culture Procedure}

The first isolation of giant viruses was conducted by directly inoculating a sample onto amoeba without a preliminary detection step. The isolation of Mimivirus in 2003 was performed following this protocol; later, the isolation of Mamavirus and Marseillevirus resulted from the direct inoculation of a large sample volume of cooling tower water that was concentrated by filtration. After the direct inoculation findings, we began to set up prospective studies of giant viruses using an antibiotic-directed procedure. The first prospective study occurred in 2010 [11] and led to the isolation of 19 giant viruses (16 Mimiviridae and 3 Marseilleviridae) by cocultivating 105 environmental samples, including cooling tower water, fresh environmental water and soil with the amoeba A. castel- lanii, and an $18 \%$ positive identification rate was achieved. In 2012, the development of high-throughput methods helped to process a greater number of samples. Of the 1,000 samples that were screened, 15 were positive $(1.5 \%$ positive) for giant viruses (4 Mimiviridae and 11 Marseilleviridae) [12].

\section{Culture Procedure with Preliminary Molecular Detection}

The first study using the culture procedure with preliminary molecular detection was conducted with standard PCR using primer pairs designed for Mimiviridae lineages A, B and C. This initial study led to 9 positive identifications from 90 soil samples ( 8 from lineage $A$ and 1 from lineage C); a $10 \%$ positive hit rate. Three of the positive samples could be isolated after culture; 2 of these belonged to lineage A (Univirus, Marais) and 1 belonged to lineage B (Ochan). More recently, the primary molecular detection system was improved by using a primerprobe system that targets lineage $\mathrm{C}$ of Mimiviridae. Using this detection strategy, 11 positive samples were detected in 156 soil samples ( $17 \%$ positive hit rate), and 8 out of 11 positive samples were cultivated (Potager, Montadette1, Montadette2, Balcon, Sete, Terrain, Feuillage and Istres; 
table 2). Surprisingly, the molecular characterisation of the 8 cultivated viruses using the specific primer-probe systems listed in the table 1 showed that Montadette 2 belongs to lineage $\mathrm{A}$ and Istres to lineage $\mathrm{B}$ of Mimiviridae. The last molecular detection system using the primerprobe system included targets for lineages A and B of Mimiviridae and for Marseilleviridae. The completed molecular detection system detected 4 positive samples from 68 samples (5.9\% positive hit rate), and all positive samples were in Mimiviridae lineage C. All 4 could be cultivated (Cornil, Saintpierre, Borely and Capucin). In our last series of 96 environmental samples, we tested the same primer-probe systems for detection in parallel and direct cultivation using isolation with additional enrichment by blind subculture. No sample was positive by PCR, but 15 (15.6\%) were positive by culture; all were Mimiviridae and included 13 from lineage A, 1 from lineage B (Cassis49) and 1 from lineage C (Luminy43).

\section{Discussion}

In Marseille, during the last decade, the first 8 giant virus isolates were isolated from cooling tower water (5 mimiviruses and 3 marseilleviruses). Later, screening of diverse environmental systems led to virus isolation from freshwater (13 Mimiviridae, 7 Marseilleviridae) and common soil (18 Mimivirus, 2 Marseillevirus). However, more unexpected environments led to the isolation of giant viruses, in particular seawater, hypersaline water and soils (5 Mimiviridae and 4 Marseilleviridae). In parallel, during a culturomic study of the human gut in 2012, the first giant virus isolated from a human sample was found in the stool of a healthy Senegalese patient (Senegalvirus, belonging to the Marseilleviridae) [6]. Another study performed in 2013 on respiratory samples of patients with pulmonary infection resulted in the isolation of the first strain of Mimiviridae in a human sample (LBA111) [14], and this study used the high-throughput method described by Boughalmi et al. [12]. With the same method, another giant virus (Shanvirus) was isolated from a stool sample and was classified in lineage $\mathrm{C}$ of Mimiviridae. A Mimiviridae lineage A (Lentille) was found in contact lens washing solution, which is related to the human environment. More recently, two strains of giant viruses isolated from animals were found in a leech (Hirudovirus, Mimiviridae lineage A) and in the larvae of the Diptera Eristalis tenax (Insectomime, Marseilleviridae) [15].

The first investigation of giant viruses focused on the water in cooling towers because the first giant virus iso-

Improvements in Mimiviridae and

Marseilleviridae Isolation from Amoeba lated, A. polyphaga Mimivirus, was found in the water of an air conditioning system. Cooling towers represent a very specific ecological system and are mostly closed systems that only slowly renew circulating water. In addition, the temperatures are favourable for several microorganisms, particularly protozoa such as amoebae [16]. Moreover, in those systems, amoebae and other microorganisms have the capacity to form biofilms, which are ideal for microbial development and are difficult to remove. The specificity of the cooling tower ecosystem could result in the best environment for the development of giant viruses because of their specific link to amoebae. Therefore, the first studies of Mimiviridae were performed on cooling tower water systems [3, 4]. However, the first giant virus prospecting study focused not only on cooling tower water but also on other types of environmental samples, such as freshwater, seawater and soil [11]. Based on this study, we noticed that giant viruses are ubiquitously distributed in all the environments studied ( $18 \%$ positive samples). The first procedure used to isolate the viruses was empirical and based on the use of antibiotics specifically adapted to the bacterial contamination encountered. The first step leading to an improvement in the giant virus isolation procedure was to decontaminate the coculture using adapted antibiotic cocktails, including antifungal agents. These cocktails were improved to exhibit better antimicrobial efficiency and to decrease toxicity against amoebae.

A second improvement was used to increase the number of samples that could be tested in parallel by establishing a high-throughput system [12]. This adaptation of the agar plate method was based on the observation that the presence of viruses can be detected by the naked eye through direct observation of a lysis plaque around the inoculation point of the enriched culture on an amoebal monolayer. This phenomenon had already been observed for chlorella viruses on agar plates coated with monocellular algae [17], and the method could be adapted to amoebae infected with giant viruses. The combination of high-throughput screening and the visual plaque assay led to the rapid isolation of 15 positive samples out of 1,000 total samples. The difference in efficiency compared with the previous study (18 vs. $1.5 \%$ positive samples) can be explained by the fact that the samples were largely taken from extreme environments, such as hypersaline water or soil. The higher amount of Marseilleviridae can also be explained by the use of preliminary filtration through $0.8-\mu \mathrm{m}$-pore filters, which is the same method that led to the isolation of Senegalvirus, the first giant virus isolated from a human stool sample [6]. However, the low rate of positive samples in cultures spurred the use 
of a second improvement to the method: the addition of a preliminary molecular detection step. Indeed, only the PCR-positive samples were cultivated, and in nearly all cases, the detected virus could be isolated. The first PCR system focused on Mimiviridae and used standard PCR with primer pairs based on the sequences of the beta subunit of the Mimiviridae DNA polymerase ( $p o l B$ ) from each lineage. The couple Mimivirus-Terra2, Moumouvirus, and the couple Courdo11-Terra1 were used to design primer pairs for lineages A, B and C, respectively. From this study, 9 PCR-positive samples from the initial 90 samples (10\%) were tested in culture, and 3 of them led to the isolation of a giant virus (Univirus, Marais and Ochan). However, the specificity of those primer pairs for the targeted group was not optimal and led to the design of primer-TaqMan probes targeting all three lineages of Mimiviridae as well as the Marseilleviridae. The first tested primer-probe targeted lineage $\mathrm{C}$ and led to the isolation of 8 Mimiviridae in 11 PCR-positive samples from 156 environmental samples. We expected that those 8 viruses would belong to lineage $C$, but, surprisingly, 1 was a lineage $\mathrm{A}$ isolate (Montadette2) and 1 was a lineage $\mathrm{B}$ isolate (Istres). It is possible that several viruses were present in the same samples and that molecular detection amplified one of them, whereas culture led to the isolation of another. The next step in culture improvement was to test the three other primer-probe systems (Mimiviridae lineage $A$ and $B$, and Marseillevirus). Using all four primerprobe systems, a series of 68 samples were analysed, and 4 were PCR positive for lineage $\mathrm{C}$ of Mimiviridae and resulted in cultivation of the correct lineage $\mathrm{C}$ viruses (Cornil, Saintpierre, Borely and Capucin). Currently, it is difficult to draw conclusions concerning the actual distribution of giant viruses in the environment. Our studies confirm the results of metagenomic data that has identified sequences related to these viruses in many environments $[18,19]$, including humans [20]. Moreover, we recently isolated a giant virus closely related to Marseillevirus from a human sample that did not grow on amoebae but did grow on cells, which demonstrates that the panel of hosts is likely not limited to Acanthamoeba, the only host utilised to isolate giant viruses up to this point [21].

Giant viruses are likely ubiquitous, as are their amoebal hosts, throughout a variety of environments. This is because it was possible to isolate giant viruses from all of the biotopes we tested, including extreme environments.

In the future, it is likely that improvements in the specific antibiotic cocktail and antibiotic concentration will increase efficiency. However, although the high-throughput procedure (allowing 50-100 samples to be tested per week) was an improvement, we believe that a higherthroughput procedure (i.e. testing up to 500 samples per week) cannot be achieved using the current technique, which is time consuming and not amenable to automation. For future work, we believe that the combination of liquid culture of amoebae in microplates with one or more blind enrichment steps and the detection of amoebal lysis by an automated flow cytometer will be the best strategy for optimal high-throughput analysis. Conversely, the use of ethanol to decontaminate samples without killing viruses, especially mimiviruses, should be a suitable alternative to the use of antibiotics in situations where cultures need to be performed on non-axenic protozoa $[22,23]$. A unique proposed alternative was published in a report related to the isolation of Megavirus chilensis [24]. In this work, the authors incubated their liquid sample for 1 month in the dark with a source of carbon, thus allowing heterotrophic bacteria to multiply. In this system, the heterotrophic bacteria serve as the food source for the protozoa present in the sample, thus expanding the virus population. This technique will have to be compared to blind enrichment, which is easier and quicker to perform. However, we believe that the best strategy for isolating these giant viruses would be to sample biofilms, where the amoeba hosts are concentrated, rather than free water.

\section{Disclosure Statement}

The authors declare that there is no potential conflict of interest or financial disclosure.

References

$>1$ La Scola B, Audic S, Robert C, Jungang L, de Lamballerie X, Drancourt M, Birtles R, Claverie JM, Raoult $\mathrm{D}$ : A giant virus in amoebae. Science 2003;299:2033.

$\checkmark 2$ Raoult D, Audic S, Robert C, Abergel C, Renesto P, Ogata H, La Scola B, Suzan M, Claverie JM: The 1.2-megabase genome sequence of Mimivirus. Science 2004;306:1344-1350.

-3 Boyer M, Yutin N, Pagnier I, Barrassi L, Fournous G, Espinosa L, Robert C, Azza S, Sun S, Rossmann MG, Suzan-Monti M, La Scola B, Koonin EV, Raoult D: Giant Marseillevirus highlights the role of amoebae as a melting pot in emergence of chimeric microorganisms. Proc Natl Acad Sci USA 2009;106: 21848-21853.

4 La Scola B, Desnues C, Pagnier I, Robert C, Barrassi L, Fournous G, Merchat M, SuzanMonti M, Forterre P, Koonin E, Raoult D: The virophage as a unique parasite of the giant mimivirus. Nature 2008;455:100-104. 
$>5$ Thomas V, Bertelli C, Collyn F, Casson N, Telenti A, Goesmann A, Croxatto A, Greub G: Lausannevirus, a giant amoebal virus encoding histone doublets. Environ Microbiol 2011;13:1454-1466.

6 Lagier JC, Armougom F, Million M, Hugon P, Pagnier I, Robert C, Bittar F, Fournous G, Gimenez G, Maraninchi M, Trape JF, Koonin EV, La Scola B, Raoult D: Microbial culturomics: paradigm shift in the human gut microbiome study. Clin Microbiol Infect 2012;18:1185-1193.

$>7$ Colson P, de Lamballerie X, Fournous G, Raoult D: Reclassification of giant viruses composing a fourth domain of life in the new order Megavirales. Intervirology 2012;55:321-332.

$>8$ Colson P, Pagnier I, Yoosuf N, Fournous G, La Scola B, Raoult D: 'Marseilleviridae', a new family of giant viruses infecting amoebae. Arch Virol 2013;158:915-920.

$>9$ Fischer MG, Allen MJ, Wilson WH, Suttle CA: Giant virus with a remarkable complement of genes infects marine zooplankton. Proc Natl Acad Sci USA 2010;107:19508-19513.

10 La Scola B, Barrassi L, Raoult D: Isolation of new fastidious a-Proteobacteria and Afipiafelis from hospital water supplies by direct plating and amoebal co-culture procedures. FEMS Microbiol Ecol 2000;34:129-137.

11 La Scola B, Campocasso A, N’Dong R, Fournous G, Barrassi L, Flaudrops C, Raoult D: Tentative characterization of new environmental giant viruses by MALDI-TOF mass spectrometry. Intervirology 2010;53:344-353.
12 Boughalmi M, Saadi H, Pagnier I, Colson P, Fournous G, Raoult D, La Scola B: Highthroughput isolation of giant viruses of the Mimiviridae and Marseilleviridae families in the Tunisian environment. Environ Microbiol 2013;15:2000-2007.

13 Gaia M, Pagnier I, Campocasso A, Fournous G, Raoult D, La Scola B: Broad spectrum of Mimiviridae virophage allows its isolation us ing a Mimivirus reporter. PLoS One 2013; 8:e61912.

14 Saadi H, Pagnier I, Colson P, Cherif JK, Beji M, Boughalmi M, Azza S, Armstrong N, Robert C, Fournous G, La Scola B, Raoult D: First isolation of Mimivirus in a patient with pneumonia. Clin Infect Dis 2013;57:e127-e134.

15 Boughalmi M, Pagnier I, Aherfi S, Colson P, Raoult D, La Scola B: First isolation of Marseillevirus in the Diptera Syrphidae Eristalis tenax. Intervirology 2013;56:386-394.

16 Pagnier I, Merchat M, La Scola B: Potentially pathogenic amoeba-associated microorganisms in cooling towers and their control. Future Microbiol 2009;4:615-629.

17 Fitzgerald LA, Wu PK, Gurnon JR, J Biffinger JC, Ringeisen BR, Van Etten JL: Isolation of the phycodnavirus PBCV-1 by biological laser printing. J Virol Methods 2010;167:223225.
Kristensen DM, Mushegian AR, Dolja VV, Koonin EV: New dimensions of the virus world discovered through metagenomics. Trends Microbiol 2010;18:11-19.

19 Steward GF, Preston CM: Analysis of a viral metagenomic library from $200 \mathrm{~m}$ depth in Monterey Bay, California constructed by direct shotgun cloning. Virol J 2011;8:287.

20 Colson P, Fancello L, Gimenez G, Armougom F, Desnues C, Fournous G, Yoosuf N, Million M, La Scola B, Raoult D: Evidence of the megavirome in humans. J Clin Virol 2013;57: 191-200.

21 Popgeorgiev N, Boyer M, Fancello L, Monteil S, Robert C, Rivet R, Nappez C, Azza S, Chiaroni J, Raoult D, Desnues C: Giant Blood Marseillevirus recovered from asymptomatic blood donors. J Infect Dis 2013, E-pub ahead of print.

22 Campos RK, Andrade KR, Ferreira PC, Bonjardim CA, La Scola B, Kroon EG, Abrahao JS: Virucidal activity of chemical biocides against mimivirus, a putative pneumonia agent. J Clin Virol 2012;55:323-328.

23 Slimani M, Pagnier I, Boughalmi M, Raoult D, La Scola B: Alcohol disinfection procedure for isolating giant viruses from contaminated samples. Intervirology 2013;56:434-440.

-24 Arslan D, LeGendre M, Seltzer V, Abergel C, Claverie JM: Distant Mimivirus relative with a larger genome highlights the fundamental features of Megaviridae. Proc Natl Acad Sci USA 2011;108:17486-17491.
Improvements in Mimiviridae and Marseilleviridae Isolation from Amoeba 